\title{
I.U.G.S. Subcommission on the Systematics of Igneous Rocks: Meeting in Grenoble, 1975
}

SIR - The following statement of the present work on the nomenclature of volcanic rocks has been issued by the Subcommision following its meeting in Grenoble in September 1975.

The IUGS Subcommission on the Systematics of Igneous Rocks and its Working Group on effusive and pyroclastic rocks held a meeting in connexion with the IUGG Congress, Grenoble, 2-4 September 1975. The participants were: F. Chayes (U.S.A.); A. Dudek (C.S.S.R.); J. Honnorez (U.S.A.); R. Ivanov (Bulgaria), M. J. Le Bas (U.K.); R. W. Le Maitre (Australia); N. P. Mikhailov (U.S.S.R.); H. de la Roche (France); P. A. Sabine (U.K.); R. Schmid (Switzerland); A. Streckeisen (Switzerland); P. M. Vincent (France); B. Zanettin (Italy). Having discussed the principles of the classification of volcanic rocks, the participants unanimously approved the following recommendations and suggestions:

(1) The classification of volcanic rocks should be consistent with the classification of plutonic rocks. Consequently, it should be based in the first instance on mineral parameters, either modal or normative.

(2) Further subdivision of any major group (e.g. basalt, andesite, rhyolite, etc.) can be achieved by using supplementary criteria. Suggestions as to suitable criteria would be very welcome.

(3) There is a need to investigate classifications, based on oxides or functions of oxides, that ideally should correspond as closely as possible to classifications by mineral parameters.

(4) To test the relationships between modal mineral contents and the various classificatory methods that are suggested, it is proposed to circulate to interested colleagues sets of chemical and modal data of selected rocks.

(5) To test further the viability of any normative calculation or any system of classification based on oxides or functions of oxides, it is proposed to circulate the suggested methods to various centres where volcanic data files exist, to determine their consistency with existing usage of nomenclature.

(6) It is felt that agreement should be sought to standardize the usage of chemical qualifiers such as, e.g. low-K, high-K, low-Si, etc. Suggestions from colleagues using such terms would be very welcome.

Suggestions may be sent to the Chairman, Prof. A. Streckeisen, Mineralog.-Petrograph. Institut, Sahlistrasse 6, CH-3012, Berne, Switzerland.

A special Working Group on pyroclastic rocks has been formed in order to discuss their classification and nomenclature and to prepare suitable recommendations. Interested colleagues may address themselves to the Chairman, Dr R. Schmid, Institut für Kristallographie und Petrographie ETH, Sonneggstrasse 5, CH-8006, Zurich, Switzerland.

Institute of Geological Sciences

P. A. SABINE

5 Princes Gate

London SW7 1QN

17th October 1975

Geol. Mag. 112 (6), 1975, p. 609. Printed in Great Britain 